Юдіна Н.В.

канд. економ. наук

Національний технічний університет Украӥни «КПІ»

\title{
ТЕХНОЛОГІЗАЦІЯ УПРАВЛІННЯ МАРКЕТИНГОВОЮ ДІЯЛЬНІСТЮ
}

\author{
ТЕХНОЛОГИЗАЦИЯ УПРАВЛЕНИЯ МАРКЕТИНГОВОЙ ДЕЯТЕЛЬНОСТЬЮ
}

\section{THE TECHNOLOGIZATION OF THE MANAGEMENT OF THE MARKETING ACTIVITY}

В роботі обтрунтовується, щзо тенденція стрімкого скорочення тривалості маркетингових планів в умовах економічної кризи пов'язана з тенденцією морального старіння традииійного підходу до управління маркетинговою діяльністю. Одним $з$ можливих інструментів подолання цієї проблеми $\epsilon$ технологізація управління маркетинговою діяльністю, щз потребувало виокремлення актуальних ї̈ напрямів. Як альтернативу традииійному підходу до управління маркетинговою діяльністю запропоновано футурологічний підхід. Він передбачатиме у процесі технологізачії необхідність переходу маркетологів з рівня споживання інформаційно-комунікаційних технологій (IКT) на рівень управління ними. У роботі обтрунтовується важливість розширення меж маркетингових досліджень, які мають передувати впровадженню IКТ в проиес управління маркетинговою діяльністю; налагодження дистаниійного формату управління маркетинговою діяльністю на базі хмарних $і$ грід-технологій; важливість самовдосконалення маркетологів за напрямом міждисииплінарних зв'язків, зокрема сингулярних і суперкомп'ютерних технологій.

Ключові слова: технологізація, управління маркетинговою діяльністю, футурологія, суперкомп'ютер, штучний інтелект, ІКТ, сингулярність

В работе обосновывается, что тенденция к стремительному сокращению сроков маркетинговых планов в условиях экономического кризиса связано с тенденцией морального старения традиционного подхода $к$ управлению маркетинговой деятельностью. Одним из возможных инструментов решения этой проблемы является технологизация управления маркетинговой деятельностью, что требует выделения актуальных ее направлений. В качестве альтернативного традиционному подходу к управлению маркетинговой деятельностью предложен футурологический подход. Он предполагает в процессе технологизации необходимость перехода маркетологов с уровня потребления информачионно-коммуникационных технологий (ИКТ) на уровень управления ими. Обоснована важность расширения границ маркетинговых исследований, которые должны предшествовать внедрению ИКТ в процесс управления маркетинговой деятельностью; налаживания дистанциионной формь управления маркетинговой деятельностью на базе облачных и грид-технологий; важность самоусовершенствования маркетологов в направлении междисииплинарных связей, в частности сингулярных и суперкомпьютерных технологий.

Ключевые слова: технологизация, управление маркетинговой деятельностью, футурология, суперкомпьютер, искусственный интеллект, ИКТ, сингулярность

The article proves that the trend of rapid reduction of terms of marketing plans during the economic crisis is related to the trend of obsolescence of the traditional approach to the 
management of the marketing activity. One of the possible instruments to deal this problem is the technologization of management of the marketing activity. It requires to allocate its topical directions. As an alternative to the traditional approach to the management of marketing activity the futurological approach was proposed. According to this approach during technologization marketers have to move from level of the consumption of information and communication technologies (ICT) to the level of the management of them. The importance of the expanding the boundaries of marketing researches which must precede implementation of ICT in the management of marketing activity was proved. The importance of the establishing of distance form of the management of the marketing activity based on cloud and grid technologies was proved. The importance of self-help marketers in the direction of learning of the interdisciplinary connections, in particular singular and supercomputer technologies, was substantiated.

Keywords: technologization, management of marketing activity, futurology, supercomputer, artificial intelligence, ICT, singularity

Вступ. За оцінкою багатьох експертів, маркетингові плани українських компаній скоротилися до одного року, що може призвести до потужного конкурентного відставання вітчизняних підприємств. Причому це стосуватиметься як відставання через втрату стратегічного плану та спроможності маркетологів передбачати майбутнє [1], так i через першопричину цього відставання у напрямку розроблення i впровадження інноваційних технологій управління маркетинговою діяльністю («технологізації», яка полягає у прискоренні генерування і абсорбції нових технологій [2]).

По-перше, скорочення тривалості маркетингових планів українських підприємств на тлі євроінтеграції, стрімких процесів розвитку інформаційнокомунікаційних технологій (IКТ), зростання неконтрольованої конкуренції 3 боку транснаціональних компаній означатиме втрату українськими підприємствами напряму свого стратегічного розвитку. Перш за все це пов'язано із тим, що під час глибоких економічних криз 2008 р. i 2014 р. на українських підприємствах зросли як ротація, так і суттєве скорочення штатів маркетологів. Для більшості компаній цілі, які раніше були спрямовані на розвиток, зараз спрямовані виключно на виживання. Але, як наслідок ротації маркетологів, кожний наступний маркетинговий план підприємства розробляється різними фахівцями (якщо взагалі розробляється фахівцями, адже в умовах економіі фінансів на посаду маркетологів частіше почали приймати непрофесійних співробітників). Підприємство в таких умовах прагне лише маркетингової адаптації до поточних ситуативних умов, залишаючись при цьому без довгострокового стратегічного плану розвитку. Це робить підприємство уразливим i неконкурентоспроможним на міжнародному глобальному ринку.

По-друге, скорочення тривалості маркетингових планів пов’язане 3 певним стереотипом неможливості для маркетолога передбачати майбутнє підприємства в умовах кризи. Однак слід враховувати, що неможливість розробляти довгострокові маркетингові плани можна пояснити або небажанням i незацікавленістю, або неспроможністю маркетологів 
передбачати майбутнє підприємства i, як наслідок, неспроможністю розробляти адекватні маркетингові плани для нього. Якщо ця ситуація пояснюється небажанням і незачікавленістю, то враховуючи періодичність ротації маркетологів на підприємствах, можна зрозуміти їх спрямованість саме на короткостроковий економічний результат, який іноді навіть може йти у розріз із довгостроковими пріоритетами підприємства.

Однак, якщо причина неможливості розробляти адекватні довгострокові маркетингові плани криється у нездатності маркетологів це робити, то це говорить про те, що маркетологи випускають 3 поля зору вплив якихось важливих факторів маркетингового середовища та не враховують їх у ході маркетингових досліджень. 3 одного боку, кризові умови вимагають професійної «мобілізації» маркетологів у напряму пошуку маркетингових інновацій для досягнення цілей не тільки виживання, але й подальшого розвитку конкретного підприємства. Це вимагатиме розширення традиційних меж маркетингових досліджень [3], оскільки даних, що аналізувалися у межах конкретних ринків раніше, у сьогоднішніх ситуативних умовах виявляється явно недостатнім для прийняття адекватних управлінських рішень. Таким чином, українські маркетологи мають зрозуміти необхідність розроблення нових технологій управління маркетинговою діяльністю. У протилежному випадку відсутність змін у технологіях управління маркетинговою діяльністю спочатку може спровокувати відставання українських маркетологів від глобальних ринкових тенденцій, а потім їх професійну деградацію. У сфері нових проблемних питань, що стоять зараз перед глобальними ринками, в які інтегрується Україна, українські маркетологи можуть втратити розуміння актуальних світових тенденцій, за напрямом яких слід прагнути інноваційних розробок. Їм залишиться лише очікувати нових маркетингових технологій, які прийдуть 3-за кордону. А це призведе до масового клонування шаблонних управлінських рішень, що означатиме швидку втрату їх ефективності. Нарощування розриву у розвитку потім буде складніше подолати, оскільки усвідомлення сутності технологічних інновацій $є$ легким лише для тих, хто постійно працює над подібними проблемами [4]. 3 іншого боку, невідповідність довгострокових маркетингових прогнозів кризовим умовам говорить про моральне старіння традиційних підходів до управління маркетинговою діяльністю.

Історичний досвід показує, що технологізація завжди ставала ефективним інструментом виходу підприємств i, навіть, країн з економічних криз. В умовах інтеграції ринків технологізація управління маркетинговою діяльністю дозволятиме виокремити інструменти подолання кризи та інструменти конкурентної боротьби на глобальних ринках, в які інтегрується сьогодні Україна. Дослідженню актуальних напрямів технологізації присвячені праці багатьох вчених, таких як, наприклад, Р. Курцвейла, Т. Фрея, Дж. Рифкина, К. Коха, Р.Солоу, Т.Коуена, Л.Піддубної, О.Шестакової, Л.Юрченко, Д.Іцкова, В.Рябініна, В. Пірогова, С. Зав'ялова, Г. Мукушева, С. 
Маркової та ін. Зокрема технологізації управлінської діяльності присвячено праці Б.Герасімова, Е.Трет'якової. При цьому аспекту актуальних напрямів технологізації управління маркетинговою діяльністю поки приділяється недостатньо уваги.

Постановка завдання. Узагальнюючи вище сказане завдання статі полягає у виокремленні актуальних напрямів технологізації управління маркетинговою діяльністю.

Методологія. Теоретико-методологічною основою проведеного дослідження стали: метод теоретичного узагальнення із залученням історикологічного підходу, порівняльного аналізу, методи маркетингових досліджень, системний підхід і теорія управління.

Результати дослідження. Технологізація управління маркетинговою діяльністю неможлива без застосування інформаційно-комунікаційних технологій (ІКТ), адже різний ступінь застосування ІКТ як різними суб'єктами ринку, так і різними співробітниками окремого підприємства може привести до виникнення соціально-економічної нерівності між ними [5]. Однією 3 гострих проблем процесу впровадження ІКТ у процес технологізації управління маркетинговою діяльністю підприємств стає споживацьке ставлення маркетологів до ІКТ у цілому. Це означатиме, що вони готові купувати різні інноваційні продукти IКТ, впроваджувати їх, але виключно як споживачі, навіть не намагаючись поглиблюватися і управляти процесом відбору ІКТ з позиції маркетингу, передаючи право прийняття рішень фахівцям 3 IT-відділів. Зазвичай головним мотивом технологізації із застосуванням ІКТ стає прагнення підвищити ефективність робочих процесів. При цьому вважається, що процес технологізації із впровадженням IКТ приноситиме виключно позитивний ефект. Але позитивний ефект проявляється не завжди, і тому маркетологам слід навчитися оцінювати та передбачати у довгостроковій перспективі також і можливий негативний ефект. Наприклад, Toyota Motor Corp. 32014 року почала поступово запроваджувати на свої заводах в Японії процеси зворотної заміни робототехнічних ліній зборки автомобільної техніки на ручну працю [6]. Цей процес отримав назву «Повернення богів». Таке рішення було пов'язано із тим, що спрямоване на випуск півмільйону автомобілів на рік виробництво почало втрачати свої показники якості: поява непоміченої роботами помилки, яка проявилася у ненавмисному пришвидшенні автомобілів Toyota, призвела до як мінімум 13 смертей власників і пасажирів цих авто. Керівництвом концерну передбачається, що люди на противагу роботам зуміють помітити нетипові дефекти та зможуть більш ретельно і нестандартно перевіряти якість своєї роботи.

Саме тому українським маркетологам потрібний футурологічний прорив як у напрямку маркетингової технологізації, так і IKT, що потребуватиме від маркетологів додаткових досліджень. Для довгострокового передбачення можливих негативних наслідків технологізації та розроблення інструментів їх 
запобігання маркетологам слід змінити підхід до управління маркетинговою діяльністю на підприємстві. За аналогією з нашою роботою [3], в якій були виокремленні підходи до маркетингових досліджень, пропонується виокремити два підходи і для управління маркетинговою діяльністю в цілому: традиційний i футурологічний підходи. Традиційний підхід передбачає адаптацію процесу управління маркетинговою діяльністю підприємства до поточного стану маркетингового середовища, виходячи при цьому 3 результатів маркетингових досліджень як поточної ситуації на ринку, так i аналогічних ситуацій у минулому. Цей підхід також можна назвати підходом «іззовні-всередину», коли поточне зовнішнє середовище визначає процеси управління маркетинговою діяльністю всередині підприємства. Слід зазначити, що наслідками саме традиційного підходу і стало споживацьке ставлення маркетологів до ІКТ, що пропонуються сьогодні на ринку. Адже IКТ маркетологи поки ще продовжують сприймати як зовнішній науковотехнічний фактор маркетингового середовища, до якого слід адаптувати процеси управління маркетинговою діяльністю шляхом активного впровадження в неї ІКТ. Однак, зазначені вище факти свідчать не тільки про падіння ефективності подібного підходу, але й навіть існування певних загроз через недооцінку довгострокового впливу цього фактору на діяльність підприємства.

Як альтернативу традиційному підходу до управління маркетинговою діяльністю нами пропонується футурологічний підхід. В основі пропонованого підходу покладається необхідність адаптації процесу управління маркетинговою діяльністю всередині підприємства не до поточного стану маркетингового середовища, а до його стану у майбутньому. Цей підхід можна порівняти 3 розвитком підприємства «з майбутнього у сьогодення». Необхідність обрання саме футурологічного підходу до управління маркетинговою діяльністю обумовлена тим, що життя людства увійшло в режим із загостреннями, при яких всі процеси прискорюються за законом експоненти [7]. Саме режими із загостреннями стали першопричиною швидкого морального застарівання технологій, скорочення життєвого циклу інновацій, невиконання традиційних законів маркетингу [8]. Така ситуація вимагає випереджальних темпів маркетингової діяльності на підприємстві і такого самого випереджального управління маркетинговою діяльністю. Це означає, що маркетологи повинні досліджувати не проблеми управління маркетинговою діяльністю, що вже стали актуальними сьогодні, i застосовувати для їх подолання технологізацію і ІКТ. Перш за все вони мають досліджувати проблеми управління маркетинговою діяльністю, що потенційно можливі у майбутньому в масштабах усього людства. I тільки після цього визначати актуальність поточної ситуації, рухаючись за часовою шкалою у зворотному напрямку. Виходячи 3 отриманих результатів таких футурологічних досліджень, маркетологи зуміють виокремити актуальні 
напрями технологізації управління маркетинговою діяльністю. Пояснимо висунуту гіпотезу.

Наприклад, прискорення процесів розвитку IKT i глобального поширення інтернету призвели до переходу звичних ринків до Інтернетринків [9]. Однією з важливих особливостей цієї нової форми ринку стала трансформація сутності поняття «ринкової влади», запропонованого наприкінці 90x років минулого століття Д. Шульцем у моделі еволюції і революції ринків [10]. Якщо на звичному ринку ринкова влада, за визначенням Д. Шульца, належала тим його суб'єктам (виробникам, посередникам, споживачам), хто володів інформацією, то на Інтернет-ринку, враховуючи широку доступність будь-якої інформації узагалі для всіх суб’єктів, сам факт володіння інформацією знецінюється. Однак, паралельно 3 цим загострюється проблема великих обсягів інформації, так званих «великих даних» («Big Data»), що генеруються і накопичуються в Інтернет-просторі. Тому ринкова влада на Інтернет-ринку переходитиме і належатиме тим його суб'єктам (виробникам контенту, провайдерам, споживачам), хто зможе управляти стрімко зростаючою інформацією (Big Data) [9]. Особливо слід відмітити, що у моделі еволюції і революції ринків Д.Шульц прогнозував, що 3 появою Інтернету ринкова влада повністю перейде до споживача. Але його прогнози виправдалися неповністю, адже на Інтернет-ринку споживач володітиме не повним обсягом інформації, а лише тією його частиною, що буде для нього доступною в Інтернеті. Тому із розвитком ІКТ ринкова влада насправді перейшла не до споживача, а до нового суб'єкту звичних ринків Інтернету, який Д. Шульц розглядав лише як новий медіа-простір для комунікацій суб'єктів звичних ринків. Але цей медіа-простір завдяки глобалізаційним процесам не тільки отримав усі ознаки ринку (як одного 3 трьох традиційних інструментів управління діяльністю людей [11]) 3 його «невидимою рукою» і відсутністю інших інструментів управління (iєрархії та культури), але й виокремив нові суб'єкти - виробників контенту, провайдерів, споживач контенту (рис. 1) [9].

Етапи еволюції Інтернет-ринків відрізнятимуться від етапів еволюції звичних ринків, що більш докладно розглядається нами у роботі [9]. Зазначимо лише, що ринкова влада зсуватиметься від виробників контенту спочатку до провайдерів, а потім до нового суб'єкту Інтернет-ринку у вигляді штучного інтелекту. При цьому слід звернути увагу, що виокремленні нами етапи еволюції Інтернет-ринків вже перетворюються на досить потужні футурологічні фактори маркетингового середовища, що впливатимуть на актуальність напрямів технологізації управління маркетинговою діяльністю. 


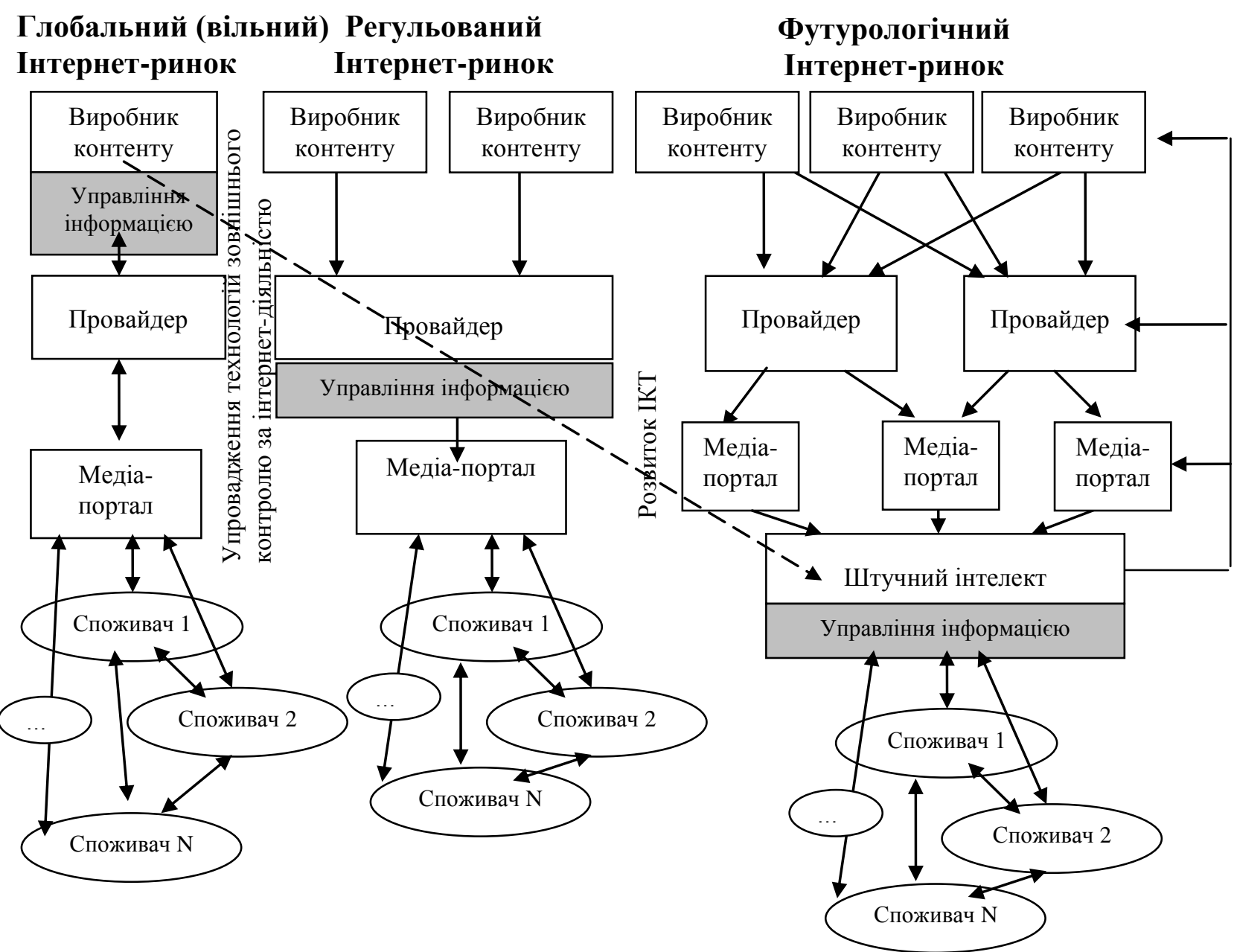

Рис. 1. Футурологічна модель еволюції та революції Інтернет-ринку [9].

По-перше, трансформація більшості звичних ринків у формат Інтернетринків, а також зміна сутності ринкової влади на них вже створили гостру необхідність масштабного переходу українських маркетологів 3 рівня лише споживання IКТ на рівень управління IKT на підприємствах. Це передбачає необхідність розуміння, усвідомлення i докладного дослідження маркетологами Інтернет-ринку, його основних тенденцій, особливостей, напрямів майбутнього розвитку. Оскільки Інтернет-ринок не обмежується територіальними кордонами, які існують на звичних ринках, маркетологам у межах аналізу факторів маркетингового середовища доведеться досліджувати тенденції планетарних масштабів: як з позиції географічного простору, так і 3 позиції часу (футурологічний простір). Це неминуче приведе до необхідності пошуку інструментів подолання проблеми Big Data в маркетинговій діяльності підприємства, у чому й має допомогти технологізація.

По-друге, поява Інтернет-ринків трансформувала підходи до офісної роботи як нових поколінь маркетологів, так i iнших співробітників підприємств, що задіяні в маркетинговій діяльності. Наприклад, серед характерних ознак нового молодого покоління офісних співробітників виокремлюють широкі, але поверхневі знання, розсіяність, синдром 
гіперактивності та дефіциту уваги, надання переваги візуальним символам замість логіки і тексту (інфографіка), ефекту фаббингу, багатозадачності, що узагальнюється під терміном «кліпове мислення» [12; 13]. Усереднений обсяг часу перебування офісних працівників підприємств під час робочого дня у соціальних мережах, який, за результатами різних досліджень, коливається від 15 хвилин до 2 годин щоденно, є демонстрацією застосування комп'ютерної техніки та IКT у середньостатистичному офісі підприємства. В умовах прискорення бізнес-процесів це означає неефективне використання ресурсів, що загрожує підприємству втратою його конкурентних позицій. Саме тому прогнозується, що на підприємствах у майбутньому зникатиме традиційне поняття «офіс», і на його зміну поступово прийде поняття «віртуальний офіс» або «віртуальне представництво». Це відбуватиметься поступово, і спочатку його мотивуючим стимулом ставатиме економія ресурсів підприємств. Наприклад, 32008 р. вимушена економія на оренді офісів, почала витісняти невеликі компанії у так звані «вільні простори» 3 наявними в них обладнаними робочими зонами із Wi-Fi, зокрема, у кафе або офісних приміщеннях бізнес-центрів, що надають послуги погодинної оренди подібних приміщень. Протягом першого півріччя 2014 р. ступінь заповнення таких робочих зон зросла майже на 20-35\% [14]. Можна передбачити, що оцінивши економію часу i ефективність віддаленої роботи співробітників, підприємства прагнутимуть і надалі взагалі не орендувати приміщень, меблів, т.і. для працівників і налагодити їх роботу у форматі віртуального офісу, за необхідності застосовуючи «вільні зони».

Розуміючи подібні глобальні тенденції, українські маркетологи повинні якнайшвидше саме в умовах кризи апробувати і перейти до дистанційного, віддаленого формату управління маркетинговою діяльністю підприємств, що дозволить ефективно перерозподілити фінансові i часові ресурси підприємства 3 утримання офісу на стратегічний розвиток підприємства на Інтернет-ринку. Це обгрунтовує другий актуальний напрям технологізації впровадження дистанційного управління маркетинговою діяльністю. Зокрема він стосуватиметься необхідності започаткувати впровадження на підприємстві хмарних технологій (cloud computing) і грід-технологій (grid). 3 одного боку, хмарні технології в гріді є інструментом подолання проблеми збереження великих даних (Big Data). Наприклад, такі IT-корпорації, як Google, вже пропонують підприємствам послуги комерційного доступу до своїх хмар. Але якщо маркетологи поставляться до цієї технології виключно зі споживацької точки зору, це може призвести або до збільшення вірогідності відкриття доступу до цих даних конкурентам, або навіть до повної втрати цих даних, що може бути пов'язане із поступовим зсуванням ринкової влади до провайдерів при переході до регульованого Інтернет-ринку (див. рис. 1). Одним 3 варіантів подолання цієї проблеми $є$ створення власного гріду в межах підприємства, який був би здатним надавати різні права доступу до сервера підприємства комп'ютерам та іншими мобільними пристроями 
співробітників відділу маркетингу та іншим працівникам компанії, задіяним у маркетинговій діяльності, які працюватимуть віддалено. Якщо маркетологи налагодять спілкування 3 такими співробітниками у форматі закритих вебінарів із шифрованою передачею даних, то особисті зустрічі взагалі стануть непотрібними. Це суттєво економитиме час і фінансові ресурси підприємства.

По-третє, реалізація подібних проектів технологізації із застосуванням ІКТ можлива лише у тісній співпраці маркетологів із ІT-спеціалістами. Але ця співпраця потребуватиме від маркетологів отримання нових знань як у напрямі IKT, так і у площині їх «проривних» міждисциплінарних NBICзв'язків (нанотехнології, біотехнології, інформаційні та когнітивні технології) [15], особливо у напрямку сингулярних технологій. Це дозволить маркетологам самостійно виокремлювати актуальні напрями технологізації управління маркетинговою діяльністю, але потребуватиме постійного оновлення знань протягом усього життя у поки ще нечітко сформованому напрямі. Сингулярні технології зосереджені на створенні людством штучного інтелекту, що необхідно для управління Big Data [16; 9]. Згідно 3 узагальненими прогнозами, технологізація суспільства може досягнути вибухоподібних темпів, що спровокує точку технологічної сингулярності або інтелектуальний вибух. Під технологічною сингулярністю слід розуміти момент створення «надрозумної машини» (штучного інтелекту) [17], яка стане здатною шляхом програмування створювати собі подібних, більш сучасні системи. Такі відомі вчені, як Р. Курцвейл, С. Хокінг, Б. Гейтс і багато інших вважають, що вірогідність технологічної сингулярності досить висока, зокрема завдяки розвитку суперкомп'ютерних технологій як окремого напряму сингулярних технологій. А це може взагалі призвести до зникнення професії «маркетолог».

Узагалі єдиної точки зору щодо визначення сутності суперкомп'ютера досі немає, але без сумніву суперкомп'ютером слід вважати систему, яка входить у останнє оновлення рейтингу Тор 500 [18], і основною ознакою суперкомп'ютера $є$ швидкість розрахунків, яка вимірюється одиницею FLOPS (кількість операцій з плаваючою точкою в секунду). Так, рейтинг Тор 500, починаючи з 1993 року, ранжує суперкомп’ютери на основі результатів виконання ними тесту LINPACK, якій грунтується на процесах розв'язування системи лінійних алгебраічних рівнянь [19]. Із загостренням проблеми зростання Big Data необхідне налагодження постійного моніторингу та управління великою системою, іiі стійкістю до відмови частини ії обладнання, планування можливих помилок, пошуку підходів до організації паралельного виконання завдань над Big Data i таке інше [20]. При цьому за п'ять років будь-який суперкомп'ютер застаріває через появу більш швидкого суперкомп'ютера, що наближуватиме швидкість суперкомп'ютерних розрахунків до швидкості роботи людського мозку. 
Так удосконалення суперкомп'ютерів стає головною передумовою появи штучного інтелекту і одним з найвпливовіших факторів технологізації управління маркетинговою діяльністю на підприємстві. Наприклад, один 3 найпотужніших за рейтингом ТОР500 суперкомп'ютер IBM Watson під час участі у дебатах популярного у США телевізійного шоу «Jeopardy!» вже продемонстрував свої надлюдські можливості, обігравши з великим відривом професійних гравців під час інтелектуальної вікторини. Знання, що використовує цей суперкомп'ютер, є результатом аналізу пошукової системи, зокрема того, що згенероване людством у Вікіпедії. Поки процес оброблення інформації суперкомп'ютером за сутністю можна порівняти із результатом роботи пошукових систем у відповідь на конкретні пошукові запити. При цьому існує прогноз, що застосування суперкомп'ютерних технологій на основі аналізу Big Data зробить можливим не тільки пошук правильних відповідей, але й генерацію нових знань шляхом їх екстраполяції. Таким чином, у маркетингу суперкомп'ютер зуміє передбачати поведінку споживачів у залежності від конкретних маркетингових заходів так само, як ці технології вже передбачають погодні явища, ступінь забруднення повітря [21] та за декілька секунд ставлять людині медичний діагноз через мобільний додаток [22]. Це також ставить під загрозу майбутнє існування такої професії, як «маркетолог».

Як бачимо, поява Інтернет-ринку потребуватиме технологізації управління маркетинговою діяльністю. Це не тільки змінює поняття ринкових стосунків, але й трансформує поняття професійної конкуренції між маркетологами, що переходитиме на рівень штучного інтелекту. Таким чином, окрім традиційних інструментів управління діяльністю людини, до яких віднесено ієрархію, культуру і ринок, також у майбутньому може долучитися ще один інструмент, а саме: штучний інтелект на базі суперкомп'ютерних технологій. Такий потенційно можливий перебіг подій може означати перехід 3 ринкової економіки на планову під управлінням штучного інтелекту, наслідки чого поки мало прогнозовані, а тому потрібно, щоб маркетологи вміли передбачати наслідки технологізації управління маркетинговою діяльністю $з$ огляду на глобальні процеси у світі. Щоб суперкомп'ютер не витіснив професію «маркетолог», маркетологи повинні розвиватися випереджаючими ці технології темпами у міждисциплінарному просторі, генеруючи нові знання, яких поки немає у Вікіпедії.

Висновки. В умовах глибокої економічної кризи, в якій зараз знаходиться Україна, та морального старіння традиційних підходів до управління маркетинговою діяльністю одним із ефективних інструментів їх подолання $\epsilon$ технологізація, що одночасно вимагає пошуку іiі актуальних напрямів. Науковою новизною дослідження є виокремлення альтернативного традиційному футурологічного підходу до управління маркетинговою 
діяльністю, що є найбільш ефективним для режимів із загостреннями, в які увійшло людство.

По-перше, трансформація звичних ринків у Інтернет-ринки, а також зміна сутності поняття «ринкова влада» вимагатимуть від маркетологів переходу з рівня споживання на рівень управління IКТ. Для цього у роботі запропоновано розширення меж маркетингових досліджень до планетарних масштабів як з географічної, так і футурологічної точки зору, що дозволить вчасно запобігати негативних наслідків впровадження окремих IКТ в процесі технологізації управління маркетинговою діяльністю.

Другим актуальним напрямом технологізації $\epsilon$ необхідність налагодження дистанційного формату управління маркетинговою діяльністю на базі хмарних і грід-технологій. Це вимагатиме від маркетологів розуміння важливості самовдосконалення протягом життя за напрямом міждисциплінарних зв'язків, зокрема сингулярних i суперкомп'ютерних технологій. У роботі підкреслена необхідність усвідомлення процесів трансформації поняття конкуренції із появою штучного інтелекту, який виокремлюється у потужний інструмент управління діяльністю людини, що за силою прирівнюватиметься до традиційних інструментів, а саме: ієрархії, культури та ринку. Це може взагалі витіснити маркетологів 3 ринку працевлаштування.

До перспективних напрямів подальших досліджень слід віднести пошук нових способів підготовки нових поколінь маркетологів, що будуть здатними управляти процесами технологізації на базі ІКТ. За ТОП-5 перспективності професій на 2017-2025 pp. WorkNew.info до найперспективніших віднесено професію «інтернет-маркетолог». 3 одного боку, це свідчить про еволюцію професії маркетолог, а з іншого, про необхідність тісної інтеграції майбутніх маркетологів із IКТ. Але через гіпершвидкі темпи розвитку ІКТ ті знання, що маркетологи отримають під час навчання у ВН3, можуть морального застаріти ще до моменту закінчення студентами вищих. Це вимагає пошуку нових інструментів підготовки майбутніх фахівців 3 маркетингу, на яких буде існувати гарантований попит на ринку у майбутньому.

\section{Література:}

1. Дорофеев В.Д. К вопросу о долгосрочном маркетинговом прогнозировании рынка / Дорофеев В.Д., Белякова В.А.// Известия ВУЗов. Поволжский регион. Общественные науки . - 2012. - №1. - С.209-216. - Режим доступа : http://cyberleninka.ru/article/n/kvoprosu-o-dolgosrochnom-marketingovom-prognozirovanii-rynka.

2. Піддубна Л.І. «Технологізація» конкурентоспроможності: теоретико-методологічні аспекти / Піддубна Л.І., Шестакова О.А. // Механізм регулювання економіки. - Харків: Видавництво ХНЕУ, 2012. - №1. - С. 1-9.

3. Юдина Н.В. Футурологический прогноз роли маркетинга в условиях глобализации мировой экономики // Инновационная экономика в условиях глобализации: современные тенденции и перспективы [Научное электронное издание] : материалы междунар. науч.-практ. конф., г. Минск, 10-11 апр. 2014 г. [Электронный ресурс] / 
Междунар. ун-т «МИТСО»; редкол.: Ю.Ю. Королев (гл.ред.) и [др.]. - Минск : Междунар. ун-т «МИТСО», 2014. - С. $370-372$.

4. Шаракшанэ С. Гетерогенный суперкомпьютер производительностью 100 триллионов операций в секунду. Интервью Б.Н.Четверушкина // https://ras.ru. - 11.01.2011. - Режим доступа : https://ras.ru/news/shownews.aspx?id=f4af6cca-e04d-48a8-9ebb-701f1431 eaa1.

5. Аніщенко О.В. Інформаційна нерівність у сучасному суспільстві [Електронний ресурс] / О.В. Аніщенко // Збірник наукових праць третьої Міжнародної науково-практичної конференції «Інформаційно-комунікаційні технології в сучасній освіті: досвід, проблеми, перспективи», 12-14 листопада 2012 р., Львів. - с.100-102. - Режим доступу : http://ubgd.lviv.ua/konferenc/kon_ikt/sekziya1/Anischenko.pdf.

6. Тoyota выгоняет роботов с заводов // Автомобильный журнал «Авторамблер». - 4 мая 2014 . - Режим доступа:

http://autorambler.ru/journal/events/04.05.2014/560987159/?gcv_source=news_block_new\&a $\mathrm{rnr}=1$

7. Князева Е. Н., Курдюмов С. П. Основания синергетики. Режимы с обострением, самоорганизация, темпомиры. - СПб., 2002. - с. 38 - 39

8. Юдина Н.В. Особенности мозговой деятельности человека как основа футурологических преобразований в маркетинге // Бренд-менеджмент. - Изд. Дом Гребенникова. - 2014. - № 3(76) - С. 164 - 175.

9. Юдина Н.В. Футурология интернет-пространства // Маркетинг услуг. - Изд. Дом Гребенникова. - 2014. - № 4 - С. 164 - 175.

10. Schultz D.E. Transitioning marketing communication into the twenty first century // Don E. Schultz, Heidi F. Schultz // Journal of marketing communications 4 9-26 (1998), P. 9-26. http://www.agora-imc.com/images/Schultz-JMC98.pdf

11. Мескон М. Х. Основы менеджмента : пер. с англ. / М. Х. Мескон, М. Альберт, Ф. Хедоури. - М. : Дело, 1992. - 702 с.

12. Фрумкин К.Г. Глобальные изменения в мышлении и судьба текстовой культуры // INETERNUM. - 2010. - №1. - Режим доступа : http://cyberleninka.ru/article/n/globalnyeizmeneniya-v-myshlenii-i-sudba-tekstovoy-kultury

13. Юдіна Н.В. E-learning-маркетинг у постсоціальному суспільстві // Маркетинг і цифрові технології. Матеріали I Міжнародної науково-практичної конференції, Одеса 29-30 травня 2014 р. - С. 218-220.

14. Бегство «белых воротничков» из киевских офисов // Портал «Финансовые новости; еfinance.com.ua. - 2014-06-03. - Режим доступу : http://e-finance.com.ua/show/181942.html.

15. Родзин С.И., Титаренко И.Н. NBIC-технологии, искусственный интеллект и электронная культура // Информатика, вычислительная техника и инженерное образование. - 2013. - № 2 (13). - Режим доступа : http://digital-mag.tti.sfedu.ru/lib/12/72013-2(12).pdf

16. Юдіна Н.В. Маркетингові аспекти футурологічних наслідків технологізації / Н.В. Юдіна // Економіка. Управління. Інноваці [Електронне фахове видання]. - 2013. - №1. Режим доступу : http://archive.nbuv.gov.ua/e-journals/eui.

17. Kurzweil R. The Singularity Is Near : When Humans Transcend Biology // R Kurzweil / Penguin Group. 2005. - 672 p.

18. Клименко В.П., Комухаев Э.И. Суперкомпьютеры: тенденции и технологии последнего двадцатилетия // Математичні машини і системи. - 2006. - №3. - Режим доступу : http://cyberleninka.ru/article/n/superkompyutery-tendentsii-i-tehnologii-poslednegodvadtsatiletiya.

19. Суперкомпьютер // Википедия. - Режим доступа : https://ru.wikipedia.org/wiki/\%D0\%A1\%D1\%83\%D0\%BF\%D0\%B5\%D1\%80\%D0\%BA\%D 0\%BE\%D0\%BC\%D0\%BF\%D1\%8C\%D1\%8E\%D1\%82\%D0\%B5\%D1\%80 
20. Абрамов С.М., Заднепровский В.Ф., Лилитко Е.П. Суперкомпьютеры «СКИФ» ряда 4 // Информационные технологии и вычислительные системы. - 2012. - №1. - С. 3-16. Режим доступа : http://www.isa.ru/jitcs/images/documents/2012-01/3_16.pdf

21. Барт А.А., Беликов Д.А., Старченко А.В. Математическая модель для прогноза качества воздуха в городе с использованием суперкомпьютеров // Вестник Томского гос. ун-та. Математика и механика. - 2011. - №3. - Режим доступа:

http://cyberleninka.ru/article/n/matematicheskaya-model-dlya-prognoza-kachestva-vozduhav-gorode-s-ispolzovaniem-superkompyuterov

22. Satish Misra, MD Watson-powered app to answer health questions based on genetic history // iMedicalApps, http://www.imedicalapps.com. - November 14, 2014. - Access : http://www.imedicalapps.com/2014/11/watson-powered-app-answer-health-questions-basedgenetic-history 